\title{
Pure Testicular Cystic Teratoma in an Adult Patient
}

\author{
Erişkin Olguda Pür Kistik Testiküler Teratom
}

\author{
Çağrı Akın Şekerci1, Güliz Yılmaz², Ișılay Bilge Yılmaz³ \\ Ilğdır State Hospital, Clinic of Urology, Iğdır, Turkey \\ 2Iğdır State Hospital, Clinic of Radiology, Iğdır, Turkey \\ 3/ğdır State Hospital, Clinic of Pathology, Iğdır, Turkey
}

\section{Pure Testicular Teratoma}

Testicular tumors are the most common solid tumors in men aged between 15 and 35 year and they account for $1-2 \%$ of all male malignancies (1). Cryptorchidism, infertility, trauma, exposure of the mother to exogenous estrogen during pregnancy and infections are the risk factors for testicular cancer. Although most of the tumors (90-95\%) originate from germ cells, they may develop from different cell types. Gonadal germ cell tumors (GCTs) of the testis are divided into two groups as seminomas and non-seminoma GTSs (NSGCTs) in which pure teratoma is a subtype of NSGCT $(1,2)$. Pure teratoma is a rare condition accounting for 2-6\% of all NSGCTs in adults. Pure form of teratoma is more common in children which constitutes $38 \%$ of testicular GCT and $3 \%$ of them in adults. They are detected more commonly in children with the incidence of the testicular GCT, 3\% in adults and $38 \%$ in children, respectively (3). Besides, pure teratomas represent $95 \%$ of all ovarian GCTs $(1,2)$. The behavior of testicular teratoma is often aggressive and depends on the patient age, but there is no relationship between the behavior of ovarian teratoma and age.

A 29-year-old male presented to our urology clinic with the complaint of a painless testicular mass. A septated avascular cystic mass was observed on ultrasound (US) with twinkling artifacts suggesting calcifications on color Doppler US (Figure 1). Testicular tumor markers, beta-human chorionic gonadotropin and alphafetoprotein, were normal before radical orchiectomy. Pathological investigation of the surgical specimen revealed pure cystic teratoma (Figure 2). Computed tomography and positron emission tomography showed a spiculated pulmonary nodule in the left lung. In the light of this finding, the patient was referred to the uro-oncology clinic and received chemotherapy after detection of the metastatic pulmonary nodule.

Teratomas consist of elements derived from more than one germ cell layer (endoderm, mesoderm and/or ectoderm). Histologically they are classified as mature, immature and malignant. Mature teratomas are well differentiated relative to the germ cell layers
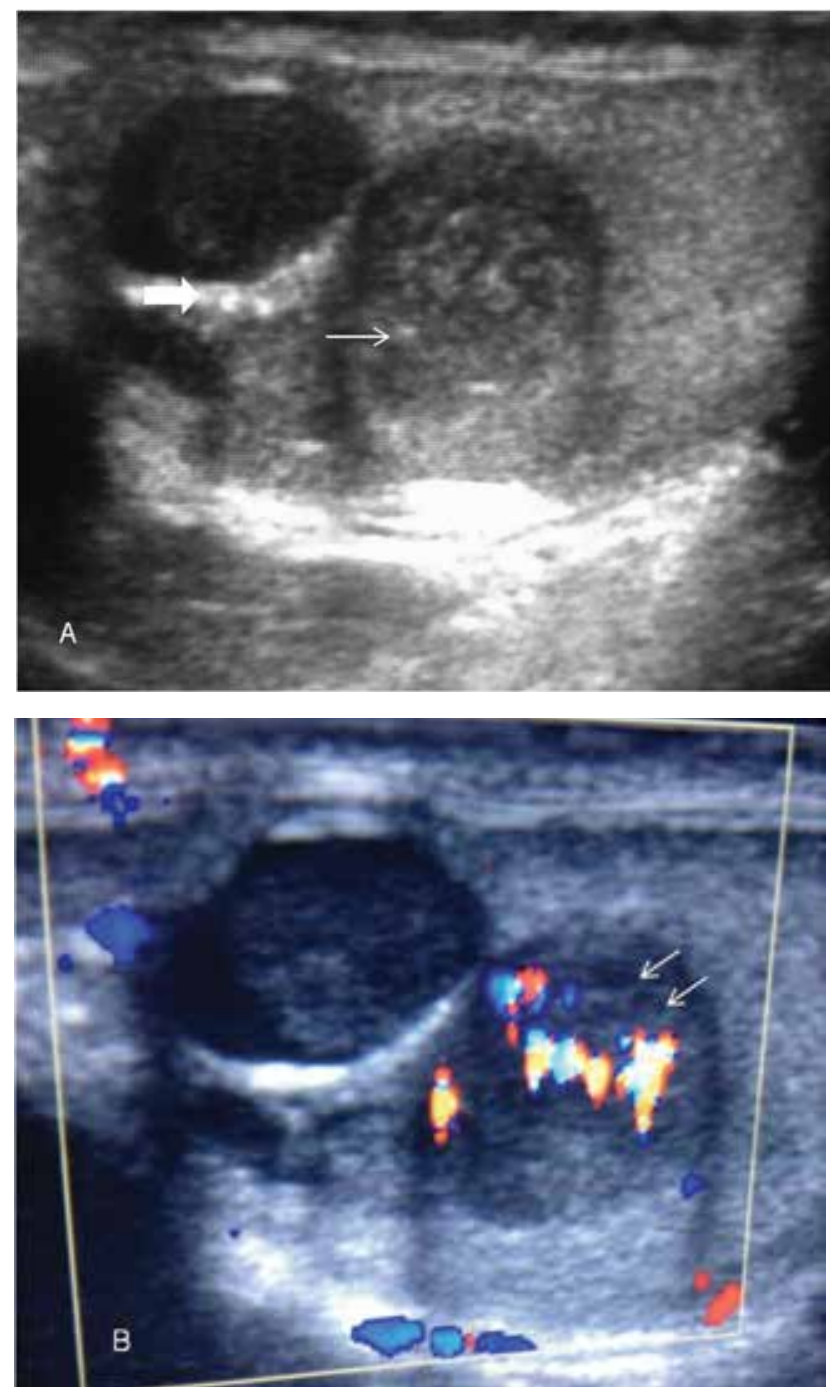

Figure 1. A) Axial ultrasound scan shows septated cystic mass (thick arrow) with internal echogenities suggesting microcalcifications (thin arrow) and B) twinkling artefacts at microcalcifications on the colour doppler ultrasound (arrows) 


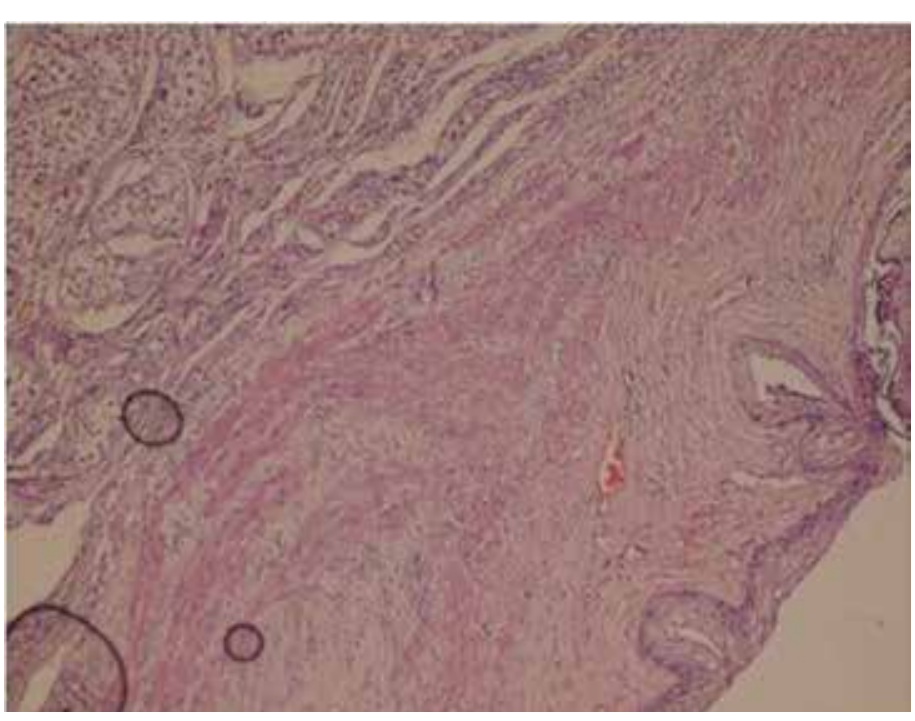

Figure 2. Mature teratoma $\left(\mathrm{HCE}_{1} \times 20\right)$ shows cyst with squamous epithelium and stromal muscle tissue

which may contain cartilage, bone, fat, muscle, and thyroid tissue. Immature forms contain incompletely differentiated components resembling embryonic and fetal tisues. Immature forms of teratomas are commonly detected in adults $(4,5)$. Testicular dermoid cysts are rare benign lesions that may be classified as a variant of mature teratoma whereas they occur in the testis without atrophy and abnormal spermatogenesis $(2,4,5)$.

Teratomas are classified as prepubertal and postpubertal according to the patient age in which they have different clinical outcome and surgery. Pure teratomas are common in prepubertal children but may behave in a malignant manner in adolescents and adults (2). Serum tumor markers are usually not elevated in pure teratoma and ultrasonographic and pathologic appearances are same between pre and post-pubertal subgroups. Metastasis from pure testicular teratoma has been reported in $29-76 \%$ of adults, however, there has been no reported case of metastasis in prepubertal group $(3,4)$. The knowledge and recognition of this rare type of teratoma can be helpful in the diagnosis.

Keywords: Teratoma, non-seminamatous germ cell tumours, pure

Anahtar Kelimeler: Teratom, seminom dışı germ hücreli tümörler, pür Authorship Contributions

Informed Consent: Consent form was filled out by all participants, Concept: Güliz Yılmaz, Çağrı Akın Şekerci, Design: Güliz Yılmaz, Data collection or Processing: Güliz Yılmaz, Çağrı Akın Şekerci, Işılay Bilge Yılmaz, Analysis or Interpretation: Güliz Yılmaz, Çağrı Akın Şekerci, Literature Search: Güliz Yılmaz, Çağrı Akın Şekerci, Writing: Güliz Yılmaz, Peer-review: Internal peer-reviewed, Conflict of Interest: The authors declared that there is no conflict of interest, Financial disclosure: No financial support was declared by the authors.

\section{References}

1. Richie JP. Detection and treatment of testicular cancer. CA Cancer J Clin 1993:43:151-175.

2. Ulbright TM. Germ cell tumors of the gonads: a selective review emphasizing problems in differential diagnosis, newly appreciated, and controversial issues. Mod Pathol 2005;18(Suppl 2):61-79.

3. Carver BS, Al-Ahmadie H, Sheinfeld J. Adult and pediatric testicular teratoma. Urol Clin Nort Am 2007;34:245-251.

4. Sesterhenn IA, Davis CJ Jr. Pathology of germ cell tumors of the testis. Cancer Control 2004;11:374-387.

5. Wetherell D, Weerakoon M, Williams DS, Beharry BK, Sliwinski A, Ow Darren, Manya K, Bolton DM, Lawrentschuk N. Mature and immature teratoma: a review of pathological characteristics and treatment options. Med Surg Urol 2014;3:124. 